\title{
HEAVY METAL PROFILES AND MICROBIAL COUNTS OF SELECTED SACHET WATER BRANDS IN BIRNIN KEBBI METROPOLIS, NIGERIA
}

\author{
${ }^{11}$ Yahaya, T., ${ }^{2}$ Doherty, V. F., ${ }^{1}$ Akinola, O.S., 'Shamsudeen, A. \\ ${ }^{1}$ Department of Biology, Federal University Birnin Kebbi, Nigeria, \\ ${ }^{2}$ Department of Biological Science, Yaba College of Technology, Lagos, \\ ${ }^{3}$ Department of Biochemistry and Molecular Biology, Federal University Birnin Kebbi, Nigeria. \\ *Author for Correspondence: yahayatajudeen@gmail.com and yahaya.tajudeen@fubk.edu.ng \\ Tel: +2348033550788 and +2348098233774
}

(Received: $28^{\text {th }}$ December, 2018; Accepted: $8^{\text {th }}$ March, 2019)

\section{ABSTRACT}

\begin{abstract}
This study evaluated the heavy metal profiles and microbial counts of 10 sachet water brands in Birnin Kebbi, Nigeria, to ascertain the safety of sachet water in the metropolis. Ten brands were randomly selected and assigned codes from KB1 to KB10, after which 15 samples from 3 batches were purchased from the vendors of each brand, making a total of 150 samples. The samples were analyzed for lead $(\mathrm{Pb})$, copper $(\mathrm{Cu}), \mathrm{cadmium}(\mathrm{Cd})$, chromium $(\mathrm{Cr})$, nickel $(\mathrm{Ni})$, and iron $(\mathrm{Fe})$ concentrations by atomic absorption spectroscopy. The bacterial count as well as coliform and yeast counts were also determined using standard protocols. The mean values of the data obtained from both analyses were then compared with World Health Organization (WHO) drinking water standards. The results showed KB2, KB4, KB7, and KB8 contained Pb above the WHO limits of $\leq 0.01$ $\mathrm{mg} \mathrm{L}^{-1}$. $\mathrm{Cu}$ and $\mathrm{Cd}$ were detected in all the brands at concentrations within the WHO limits of $\leq 1.0 \mathrm{mg} \mathrm{L}^{-1}$ and $\leq$ $0.003 \mathrm{mg} \mathrm{L}^{-1}$, respectively. The levels of $\mathrm{Cr}$ in $\mathrm{KB} 1, \mathrm{~KB} 3$, and $\mathrm{KB} 8$ were higher than $\leq 0.05 \mathrm{mg} \mathrm{L}^{-1} \mathrm{WHO}$ limits, while other brands were within the range. KB3, KB4, KB5, and KB7 exceeded $\leq 0.02 \mathrm{mg} \mathrm{L}^{-1}$ WHO limits for Ni. In the case of Fe, only KB8 and KB9 were found within the normal range of $\leq 0.3 \mathrm{mg} \mathrm{L}^{-1}$. All the brands had bacterial counts above the WHO limits $\left(\leq 100 \mathrm{cfu} \mathrm{ml}^{-1}\right)$, and only KB6 had coliform counts higher than the WHO limits $\left(\leq 0 \mathrm{cfu} \mathrm{ml}^{-1}\right)$. Of all the brands, only KB3, KB7 and KB10 contained yeast beyond the WHO limits $\left(\leq 50 \mathrm{cfu} \mathrm{m}^{-1}\right)$. These results showed the water samples were seriously contaminated, and the water brands could pose a significant public health risk to the consumers in the city if this trend continues.
\end{abstract}

Keywords: Bacterial count, Heavy metals, Microbe, Sachet water, Serial dilution.

\section{INTRODUCTION}

The United Nations describes free access to clean water as a basic human right and one of the indices of good living (CDC, 2012). Clean water is necessary for social development, justice and welfare; so important it was tagged as the earth's milk (Sharad and Vijay, 2010). On average, an individual needs between 20 and 50 liters of clean and safe water daily for drinking and domestic activities (CDC, 2012). Unfortunately, water quality and availability are declining worldwide (Sharad and Vijay, 2010). At least one in six people, particularly in developing nations, lack adequate access to clean and safe water (NAS, 2007). This phenomenon has contributed significantly to the rising incidence of many diseases worldwide. Liu et al. (2012) reported that about 1.8 million people, mostly children and women die every year from waterborne diseases like cholera, diarrhea and dysentery. Increasing environmental pollution due to urbanization and industrialization had been linked to declining water quality worldwide (Sharad and Vijay, 2010).

Heavy metal pollution is particularly being blamed for the increasing contamination of water worldwide. A heavy metal is a dense metal that is (usually) toxic at low concentrations (Duffus, 2002). The most frequently detected heavy metals in water include arsenic, cadmium, chromium, copper, lead, nickel, and zinc (Lambert et al., 2000). Various sources of heavy metals in water include soil erosion, weathering, mining, industrial wastewaters, urban runoff, sewage discharge, dumpsites, agrochemicals, among others (Morais et al., 2012). Substances containing heavy metals have been implicated in a lot of diseases, including respiratory diseases, genetic diseases, hematological problems, skin damage, sight problems, brain damage, etc. (Yahaya and Okpuzor, 2011). Microbial infection is also increasingly being implicated in the contamination 
of drinking water and increasing incidence of waterborne diseases (Pandey et al., 2014). There are more than 500 waterborne pathogens capable of contaminating drinking waters, and are grouped into mainly viruses, bacteria, parasitic protozoa, and fungi (Soller et al., 2010).

Preventing the burdens of contaminated water requires adequate monitoring and treatment of various water sources in each community. These require a series of measures, among which is the identification and quantification of various contaminants in community drinking water supplies. A safe drinking water must have some properties specified by WHO and various national agencies (NAS, 2007). Like most towns and cities in Nigeria, sachet water, popularly called 'pure water,' is the most common source of drinking water in Birnin Kebbi. However, to the best of our knowledge, no study has been conducted on the safety of this form of drinking water in the city as outlined by WHO. A study focusing on this becomes imperative considering the rate at which heavy metal poisonings and waterborne diseases are being reported in the neighbouring states. To this end, this study assessed the heavy metal levels and microbial loads of selected sachet water brands sold in Birnin Kebbi metropolis.

\section{MATERIALS AND METHODS}

\section{Description of the Study Area}

This study was carried out in Brinin Kebbi metropolis, which lies between latitude $12^{\circ} 27^{\prime}$ 57.8808" $\mathrm{N}$ and longitude $4^{\circ} 11^{\prime} 58.2864^{\prime \prime} \mathrm{E}$ (Figure 1). Birnin Kebbi is the capital of Kebbi state and Headquarters of Gwandu emirate in the northwestern Nigeria. It lies along the SokotoKebbi River at the intersection of roads from Argungu, Jega, and Bunza.

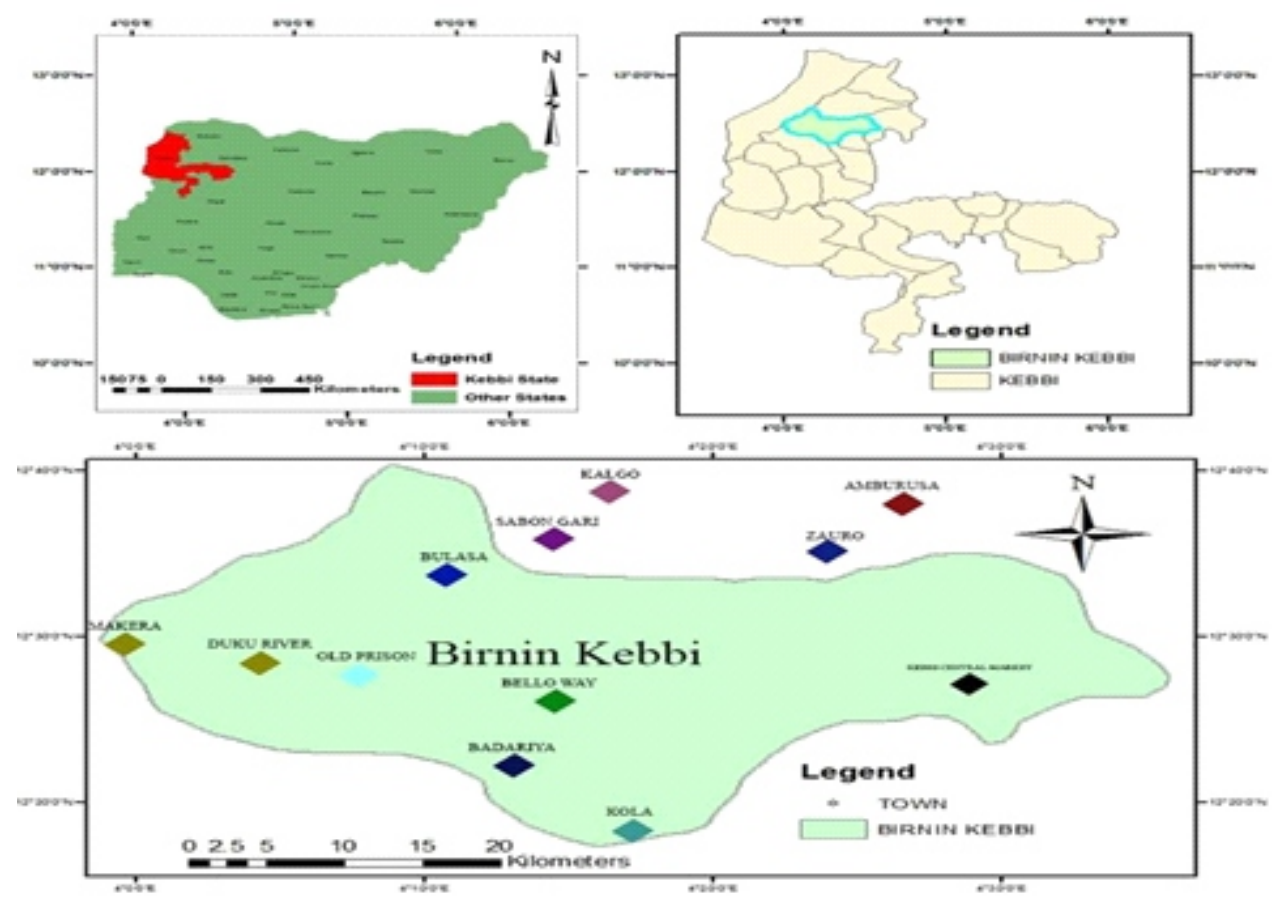

Figure 1: Map Showing the Location of Birnin Kebbi

\section{Source of Materials}

Ten (10) sachet water brands sold in Birnin Kebbi metropolis were randomly selected for this study and assigned codes from KB1 through KB10 to protect the privacy and right of the manufacturers. Fifteen samples from 3 batches were purchased from the vendors of each brand in November, 2018, making 150 samples in all. The samples were carried into the laboratory in sterilized polythene bags, labeled appropriately and stored in a refrigerator at $4{ }^{\circ} \mathrm{C}$ prior to analysis. The samples were later screened for lead $(\mathrm{Pb})$, copper $(\mathrm{Cu})$, cadmium (Cd), chromium (Cr), Nickel $(\mathrm{Ni})$, and iron $(\mathrm{Fe})$ concentrations as well as bacterial, coliform and yeast counts. 
All the reagents used for the analyses, including an aqua-regia solution (3:1 mixture of concentrated $\mathrm{HNO}_{3}$ and $\mathrm{HCl}$ ) were prepared from chemicals of analytical reagent grade (AnalaR) and deionised water. The plastic containers and glass wares used were also thoroughly washed with a detergent solution, and then rinsed properly with tap water followed by deionised water and the respective water samples.

\section{Heavy Metal Analysis}

About $0.5 \mathrm{ml}$ of each water sample was mixed with $25 \mathrm{ml}$ aqua-regia solution in the digestion tube and then digested at $120{ }^{\circ} \mathrm{C}$ for 3 hours. The digested material was filtered into $100 \mathrm{ml}$ beaker, and the solution was analyzed for the selected heavy metals using Atomic Absorption Spectrometer (UNICAM model 969) (Adelaja et al., 2012).

\section{Bacteria Count Detection Test}

Nutrient agar medium containing, in $\mathrm{g} / \mathrm{L}$, casein hydrolysate 4.0 , yeast extract 3.0 , glucose 2.0 , beef extract 1.5, peptone 6.0 and agar $20.0(\mathrm{pH} \mathrm{7.0)}$ were prepared in Petri plates. About $0.5 \mathrm{ml}$ of each water sample was transferred into a plate and then incubated at $37^{\circ} \mathrm{C}$ for $24-48$ hours. Each sample was run in triplicates (Feng et al., 2002), and the total number of colonies in each plate was counted with the help of colony counter. The Colony Forming Unit (CFU) was estimated using the formula: $\mathrm{CFU}=$ Number of Colonies $\mathrm{x}$ Dilution Factor/Sample Volume (ml).

\section{Coliform Detection Test}

The coliform detection was carried out by standard multiple tube fermentation technique consisting a series of preliminary and confirmatory tests. Presumptive test was carried out using lactose broth medium containing malt extract $(3.0 \mathrm{~g} / \mathrm{L})$, peptone $(10 \mathrm{~g} / \mathrm{L})$, lactose $(5.0$ $\mathrm{g} / \mathrm{L})$ and bromothymol blue indicator $(1.0 \mathrm{~g} / \mathrm{L})$. Ten (10) $\mathrm{ml}$ of the medium was transferred into test tubes after which inverted Durham tubes and $5 \mathrm{ml}$ of water sample were added to it. After 24hour incubation at $37^{\circ} \mathrm{C}$, the test tubes were examined for the presence of acid and gas. Acid production was indicated by a change in colour, while gas production was indicated by the accumulation of gas bubbles in the inverted
Durham tubes. A confirmatory test was conducted using Eosine Methylene Blue (EMB) agar medium containing peptone $(10 \mathrm{~g} / \mathrm{L})$, potassium phosphate $(2.0 \mathrm{~g} / \mathrm{L})$, lactose $(1.0$ $\mathrm{g} / \mathrm{L})$, eosin Y $(2.0 \mathrm{~g} / \mathrm{L})$, methylene blue $(1.3 \mathrm{~g} / \mathrm{L})$ and agar $(20 \mathrm{~g} / \mathrm{L})$. A loop full of culture from each positive fermentation tube was streaked over the sterile agar EMB plates. The plates were incubated at $37^{\circ} \mathrm{C}$ for 24 hours. A final check of colonies that appeared after the confirmatory test was performed by growing the colonies on the nutrient agar slant and in Durham tubes containing lactose broth. After incubation for 24 hours at $35^{\circ} \mathrm{C}$, the lactose broth was examined for the production of gas. Bacteria cultures from nutrient agar slants were used to prepare a slide and, after gram staining, it was examined under the microscope. The presence of gram negative, nonspore forming rod that ferment lactose, confirmed the presence of coliforms in the water samples (Feng et al., 2002).

\section{Yeast Detection Test}

About $0.5 \mathrm{ml}$ of each water sample was transferred into a Petri plate containing malt agar medium and yeast extract peptone dextrose (YPD) medium and incubated at $25-30{ }^{\circ} \mathrm{C}$. The malt agar was composed of malt extract 3\%, mycological peptone $0.5 \%$ and agar $1.5 \%, \mathrm{pH} 5.5$, while the YPD agar medium was prepared from yeast extract $1 \%$, peptone $2 \%$, dextrose $2 \%$, agar $1.5 \%$ and ampicillin $100 \mu \mathrm{g} / \mu \mathrm{l}(\mathrm{pH}$ 6.5). After 24 to 72 hours of incubation, the number of yeast colonies was counted using colony counter (Feng etal., 2002).

\section{Statistical Analysis of Results}

Data were expressed as Mean \pm Standard Deviation using the statistical package for social science version 20 .

\section{RESULTS}

\section{Levels of the Selected Heavy Metals in the Sachet Water Brands}

Table 1 shows the levels of selected heavy metals in the analyzed sachet water brands. $\mathrm{Pb}$ was recorded at concentrations above the WHO limits in $\mathrm{KB} 2, \mathrm{~KB} 4, \mathrm{~KB} 7$, and $\mathrm{KB} 8$, while other brands were within the normal range. With regard to $\mathrm{Cu}$ 
and $\mathrm{Cd}$, all the brands had normal concentrations. In the case of $\mathrm{Cr}, \mathrm{KB} 1, \mathrm{~KB} 3$, and $\mathrm{KB} 8$ had abnormal levels, while other brands were within the normal range. Ni was detected at levels beyond the WHO limits in KB3, KB4, KB7 and KB8, while other brands contained normal levels of the metal. All the brands contained abnormally high concentrations of Fe except KB8 and KB9.

\section{Table 1: Levels of Selected Heavy Metals (mg L $\left.\mathrm{m}^{-1}\right)$ Detected in the Sachet Water Brands}

\begin{tabular}{lllllll}
\hline Water Brand & Pb & Cu & Cd & Cr & Ni \\
KB1 & $0.008 \pm 0.00026$ & $0.287 \pm 0.000224$ & $0.001 \pm 0.00$ & $0.10 \pm 0.0005$ & $0.036 \pm 0.000494$ & $0.472 \pm 0.000577$ \\
KB2 & $0.031 \pm 0.00031$ & $0.310 \pm 0.000401$ & ND & $0.03 \pm 0.0004$ & $0.009 \pm 0.000211$ & $0.643 \pm 0.000422$ \\
KB3 & $0.001 \pm 0.00042$ & $0.211 \pm 0.000211$ & ND & $0.12 \pm 0.0003$ & $0.037 \pm 0.000792$ & $0.722 \pm 0.000422$ \\
KB4 & $0.021 \pm 0.00318$ & $0.441 \pm 0.000342$ & ND & $0.03 \pm 0.0003$ & $0.038 \pm 0.000333$ & $0.521 \pm 0.000401$ \\
KB5 & $0.001 \pm 0.00021$ & $0.428 \pm 0.000494$ & ND & $0.02 \pm 0.0004$ & $0.008 \pm 0.000365$ & $0.556 \pm 0.000447$ \\
KB6 & $0.008 \pm 0.00031$ & $0.33 \pm 0.000342$ & $0.001 \pm 0.0002$ & $0.04 \pm 0.0002$ & $0.005 \pm 0.000342$ & $0.387 \pm 0.000447$ \\
KB7 & $0.029 \pm 0.00032$ & $0.607 \pm 0.000477$ & $0.001 \pm 0.0002$ & $0.03 \pm 0.0004$ & $0.029 \pm 0.000224$ & $0.392 \pm 0.000477$ \\
KB8 & $0.021 \pm 0.00033$ & $0.539 \pm 0.000307$ & ND & $0.08 \pm 0.0003$ & $0.005 \pm 0.00000$ & $0.262 \pm 0.000703$ \\
KB9 & ND & $0.342 \pm 0.000447$ & ND & $0.02 \pm 0.0004$ & $0.019 \pm 0.00000$ & $0.227 \pm 0.002113$ \\
KB10 & $0.009 \pm 0.00031$ & $0.604 \pm 0.000307$ & $0.001 \pm 0.00$ & $0.02 \pm 0.0003$ & $0.016 \pm 0.000447$ & $0.473 \pm 0.000615$ \\
WHO (2003) & $\leq 0.01$ & $\leq 1.0$ & $\leq 0.003$ & $\leq 0.05$ & $\leq 0.02$ \\
\hline
\end{tabular}

Values were expressed as Mean \pm SD; ND = Not detected; WHO (2003) - World Health Organization Limit

\section{Microorganisms Isolated from the Water Brands}

Table 2 shows the counts of the microorganisms isolated from the water brands. Bacterial colonies were detected above the WHO limits in all the brands. In the coliform detection test, only KB9 revealed abnormal levels, while other brands were normal. Yeast was recorded above the normal range in $\mathrm{KB} 3, \mathrm{~KB} 7$, and $\mathrm{KB} 10$, whereas other brands were within the WHO limits.

\section{Table 2: Microorganisms $\left(\mathrm{cfu} \mathrm{m}^{-1}\right)$ Isolated from the Sachet Water Brands}

\begin{tabular}{llll}
\hline Water Brand & Bacterial Count & Coliform Count & Yeast Count \\
KB1 & $1100.00 \pm 28.00$ & ND & ND \\
KB2 & $1500.00 \pm 40.00$ & ND & ND \\
KB3 & $1500.00 \pm 37.00$ & ND & $1116 \pm 44.00$ \\
KB4 & $1500.00 \pm 60.00$ & ND & ND \\
KB5 & $1500.00 \pm 53.60$ & ND & ND \\
KB6 & $4100.00 \pm 28.00$ & $90.00 \pm 6.00$ & ND \\
KB7 & $1500.00 \pm 49.00$ & ND & $1123 \pm 19.00$ \\
KB8 & $4100.00 \pm 50.00$ & ND & ND \\
KB9 & $1000.00 \pm 50.00$ & ND & ND \\
KB10 & $1500.00 \pm 60.00$ & ND & $1105 \pm 28.15$ \\
WHO Limits, 2008 & $\leqslant 100 \mathrm{cfu} \mathrm{mll}$ & $0 \mathrm{cfu} 100 \mathrm{ml}^{-1}$ & $\leqslant 50 \mathrm{cfful}^{-1}$ \\
\hline
\end{tabular}

\section{DISCUSSION}

The safety status of selected sachet water brands sold in Birnin Kebbi, Nigeria with regard to heavy metal profiles and microbial loads was determined in this study. The majority of the selected heavy metals were detected at abnormal levels in the water brands (Table 1). KB1, KB3, $\mathrm{KB} 4$, and $\mathrm{KB} 7$ were the most contaminated as each contained three heavy metals at concentrations above the WHO limits, followed by KB2 and KB8 with two heavy metals each. Comparatively, KB5 and KB6 were fairly polluted as each had an excess of only Fe, while only KB9 was free of the tested heavy metals. These findings show drinking water in Birnin Kebbi may be grossly contaminated with heavy metals and pose a significant health threat to the consumers. Similar observations were reported by Shabanda et al. (2014) who detected certain heavy metals in boreholes and wells in Aliero metropolis, some kilometers from Birnin Kebbi. Yahaya et al. (2010) also found elevated levels of heavy metals in soil samples collected from road sides in Yauri metropolis, Kebbi state. Most of the sachet water 
sold in Birnin Kebbi comes from rivers, boreholes and wells, so contamination of surface and ground water could be blamed for the high levels of heavy metals detected. According to Egwari and Aboaba (2002), natural processes and anthropogenic activities can contaminate groundwater, and such activities could be domestic, agricultural or industrial in nature.

The detection of bacterial colonies above the WHO limits in all the water samples (Table 2) is an indication the water samples were prepared under poor sanitary conditions. Similar results were reported by Gulumbe et al (2016) who isolated several bacterial colonies from a dam in Aliero. Jega et al (2017) also detected Salmonella typhi, Escherichia coli, Citrobacter species, Enterobacter species and Serratia marcescens in a public water supply in Birnin Kebbi. The detection of microorganisms in the studied sachet water further shows the water brands are not suitable for consumption. Some bacteria species can cause cholera, diarrhea, dysentery, respiratory diseases, gastrointestinal diseases, etc. (Igarashi et al., 2017). Coliforms were detected in KB6, which again reveals the unhealthy state of the brand. Coliforms are ideally found in the soil, in water that has been influenced by surface water, and in human or animal waste (NYSDH, 2017). Though most coliforms do not cause diseases, some rare strains of $E$. coli, particularly the 0157:H7 can cause serious illness (NYSDH, 2017). Yeast was found in KB3, KB7 and KB10, which also further proves the water brands are not safe for drinking. Certain yeast can cause allergic reactions, and some are human pathogens (Patterson and Lima, 2005). Moreover, toxic compounds can be produced by yeast, often referred to as mycotoxins (Patterson and Lima, 2005).

\section{CONCLUSION}

From the results of this study, it can be concluded that the selected sachet water brands were highly contaminated with heavy metals, except KB9. It is also clear from the study that the water samples were seriously contaminated with bacterial colonies. Consequently, all the studied water brands are not suitable for consumption as they pose a significant public health risk. While we recommend more studies in this direction to verify our claims, we advise government agencies saddled with public health in the city to put in place appropriate measures to ensure safe drinking water.

\section{REFERENCES}

Adelaja, O. A., Okoronkwo, A. E. and Abass, L.T. 2012. Investigation of heavy metals binding to Jatropha curcas husk. Nature and Science, 10(3): 1-6.

Center for Disease Control, CDC. 2012. Global water, sanitation, and hygiene (WASH). Available at https://www.cdc.gov/ healthywater/global/healthburden.html (Accessed June 25 $5^{\text {th }}, 2018$ ).

Duffus, J.H. 2002. Heavy metals-a meaningless term? Pure and Applied Chemistry, 74(5): 793-807.

Egwari, L. and Aboaba, O.O. 2002. Bacteriological quality of domestic waters reverse edition. Saude Publica, 36(4): 513-520.

Feng, P., Stephen, D., Weagant, R., Grant, M.A. and Burkhar, W. 2002. Enumeration of Escherichia coli and the coliform bacteria. Bacteriological analytical manual, Chapter 4. pp:1-7. Available online at http://www.academia.edu /23345561/Bacteriological_Analytical_ Manual (Accessed June 26 $6^{\text {th }}, 2018$ ).

Gulumbe, H.B., Aliyu, B. and Manga, S.H. 2016. Bacteriological and physicochemical analyses of Aliero Dam water. International Journal of Innovative Studies in Sciences and Engineering Technology, 2(4): 30-34.

Igarashi, H., Nago, N., Kiyokawa, H. and Fukushi, M. 2017. Abdominal pain and nausea in the diagnosis of streptococcal pharyngitis in boys. International Journal of General Medicine, 10:311318.

Jega, B.G., Abubakar, U. and Mange, S.S. 2017. Detection of coliform from public water supply in Birnin Kebbi metropolis, Kebbi State, North-Western Nigeria. ATBU Journal of Science, Technology andEducation, 5 (3): 96-103.

Lambert, M., Leven, B.A., and Green, R.M. 2000. 
New methods of cleaning up heavy metal in soils and water; Environmental science and technology briefs for citizens; Manhattan, KS: Kansas State University. Available online at https://cfpub. epa.gov/ncer_abstracts/index.cfm/fuse action/display.files / fileID / 14295 (Accessed on June $26^{\text {th }}, 2018$ ).

Liu, L., Johnson, H.L., Cousens, S., Perin, J., Scott, S., Lawn, J.E., Rudan, I., Campbell, H., Cibulskis, R., Li, M., Mathers, C. and Black, R.E. 2012. Child health epidemiology reference group of WHO and UNICEF. Global, regional, and national causes of child mortality: an updated systematic analysis for 2010 with time trends since 2000. Lancet, 379 (9832): 2151-61

Morais, S., Costa, F.G. and Pereira, M.L. 2012. Heavy metals and human health. In: Oosthuizen J, editor. Environmental health - emerging issues and practice. pp. 227-246.

National Academy of Science, NAS. 2007. Safe drinking water is essential. Available online at http://www.koshland-sciencemuseum.org/water/html/en/Overview /index.html (Accessed May $5^{\text {th }}, 2018$ ).

New York State Department of Health, NYSDH. 2017. Coliform bacteria in drinking water supplies. Available online at https://www.health.ny.gov/ environmental/water/drinking/colifor m_bacteria.htm (Accessed May $\left.5^{\text {th }}, 2018\right)$.

Pandey, P.K., Kass, P.H., Soupir, M.L., Biswas, S. and Singh, V.P. 2014. Contamination of water resources by pathogenic bacteria. $A M B$ Express, 4: 51.

Patterson, R. and Lima, N. 2005. Fungal contamination of drinking water. In book: Water encyclopedia. doi:
10.1002/047147844X.wq1516

Shabanda, I.S., Kilgori, S.A., Umar, S. and Aminu, M.H. 2014. Selected trace heavy metals concentrations in well and borehole water in Aliero metropolis. International Research Journal of Pure and Applied Chemistry, 4(6): 880-886

Sharad, K.J. and Vijay P.S. 2010. Water crisis, Journal of Comparative Social Welfare, $26(2-3): 215-237$.

Soller, J.A, Bartrand, T., Ashbolt, N.J., Ravenscroft, J. and Wade, T.J. 2010. Estimating the primary etiologic agents in recreational freshwaters impacted by human sources of faecal contamination. Water Research, 44(16): 4736-47.

World Health Organization, WHO. 2003. International year of freshwater. General assembly resolution A/RES/55/196. Available at http://www.wateryear 2003.org/. (Accessed on June $20^{\text {th }}, 2018$ ).

World Health Organization, WHO. 2008. Guidelines for Drinking water- Quality: Incorporating the first and second addenda volume1: Recommendations. World Health Organization, Geneva, Switzerland. Available at https://www.who.int/water_sanitation_ health/dwq/secondaddendum20081119 .pdf (Accessed on June 30 ${ }^{\text {th }}, 2018$ ).

Yahaya, M.I., Ezeh, G.C., Musa, Y.F. and Mohammad, S.Y. 2010. Analysis of heavy metals_concentration in road sides soil in Yauri, Nigeria. African Journal of Pure and Applied Chemistry, 4(3): 022-030.

Yahaya, T., Okpuzor, J. 2011. Variation in exposure to cement dust in relation to distance from Cement Company. Research Journal of Environmental Toxicology, 5(3): 203-212. 